$\begin{array}{llllllllllllll}\text { A C T A } & \text { C H E M I C A } & \text { S C A N D I N A V I C A } & 26 & (1972) & 585-595\end{array}$

\title{
The Amino Acid Sequence of Viscotoxin A2 from the European Mistletoe (Viscum album L., Loranthaceae)
}

\author{
THOMASOLSON and GUNNAR SAMUELSSON
}

Department of Pharmacognosy, Farmaceutiska Fakulteten, Lindhagensgatan 128, S-112 51 Stockholm, Sweden

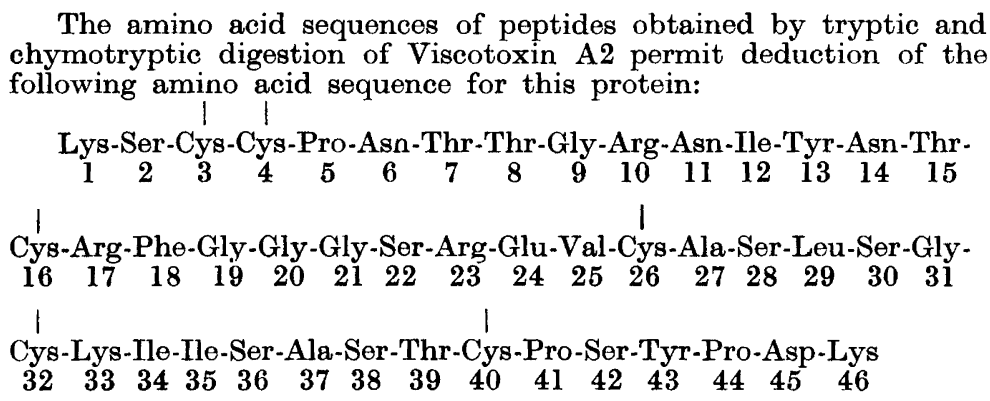

$\mathrm{V}$

iscotoxin is a mixture of pharmacologically active, small, basic proteins isolated from the European mistletoe, Viscum album L.1,2 One component of this mixture is Viscotoxin A2, which can be isolated from Viscotoxin by chromatographic methods as previously described. ${ }^{3,4} \mathrm{Viscotoxin} \mathrm{A} 2$ is composed of 46 amino acid residues and has a molecular weight of 4833.4 This paper describes the determination of the amino acid sequence of Viscotoxin A2.

\section{EXPERIMENTAL}

\section{Materials and apparatus}

$V$ iscotoxin $A 2$ was obtained either as the oxidized product Viscotoxin Aox2 by chromatography of oxidized Viscotoxin on cellulose phosphate and DEAE-cellulose, ${ }^{3}$ or as the native material by chromatography of Viscotoxin on SE-Sephadex."

Enzymes. Trypsin, chymotrypsin, leucine aminopeptidase, carboxypeptidases $\mathbf{A}$ and B. The sources and treatments of these enzymes have been described previously. ${ }^{5}$

Dansyl chloride (1-dimethylamino-naphthalene-5-sulfonyl chloride) was obtained from Sigma or Pierce Chemical Co. The substance was dissolved in acetone, filtered to remove insoluble hydrolysis products, and the solution evaporated to dryness in vacuo in a rotary evaporator. The dry material was dissolved in acetone to a concentration of $10 \mathrm{mg} / \mathrm{ml}$, and the solution stored in a glasstoppered bottle over silica gel in the dark.

Acta Chem. Scand. 26 (1972) No. 2 
Sephadex G-10, G-15, and G-25, Pharmacia Fine Chemicals, Uppsala, Sweden. $S E$-Sephadex C-25, Pharmacia Fine Chemicals, Uppsala, Sweden.

$p H$-stat, Radiometer titrator TTTle with titrigraph SBR2c. Radiometer, Copenhagen, Denmark.

\section{Methods}

Performic acid oxidation of $V$ iscotoxin $A 2$ was performed at $0^{\circ} \mathrm{C}$ as described by $\mathrm{Hirs}^{\circ}$

Digestion with trypsin and chymotrypsin. $220 \mathrm{mg}$ oxidized Viscotoxin A2 was digested with trypsin at $\mathrm{pH} 8.5$ and $37^{\circ} \mathrm{C}$ for $8 \mathrm{~h}$ in the $\mathrm{pH}$-stat, using a previously described procedure. ${ }^{5}$ The final enzyme : protein ratio was $1: 30(\mathrm{w} / \mathrm{w})$. The same technique was used for digestion of $195 \mathrm{mg}$ oxidized Viscotoxin A2 with chymotrypsin at $\mathrm{pH} 8.5$ and $37^{\circ} \mathrm{C}$ for $5 \mathrm{~h}$ at a final enzyme : protein ratio of $1: 30(\mathrm{w} / \mathrm{w})$.

Separation of tryptic peptides. The tryptic hydrolysate was subjected to gel filtration on a column $(1 \times 500 \mathrm{~cm})$ of Sephadex G-25, with $10 \%$ acetic acid as eluent. The column consisted of a tube made of polyvinyl chloride, suspended in a vertical position between two floors in the laboratory. $5 \mathrm{ml}$ fractions were collected, and their O.D. at $280 \mathrm{~nm}$ deter. mined. Two peaks were obtained. The peptides of these peaks were separated by chromatography on Dowex 1-X2 following the procedure of Schroeder et al. ${ }^{7}$ with previously described modifications. ${ }^{5}$ The eluate from the Dowex 1-X2 chromatography was analyzed for content of peptides by thin-layer chromatography, of $60 \mu \mathrm{l}$ aliquots from each third fraction of the eluate. Plates, $20 \times 40 \mathrm{~cm}$, coated with a $0.25 \mathrm{~mm}$ layer of Silica gel $\mathrm{G}$ (Merck) were used. The plates were developed with propanol : conc. ammonia : water $(60: 6: 34)$, dried, and sprayed with ninhydrin reagent $(0.05 \mathrm{~g}$ ninhydrin, $50 \mathrm{ml}$ ethanol, $2 \mathrm{ml}$ collidine and $15 \mathrm{ml}$ acetic acid) and heated $5 \mathrm{~min}$ at $105^{\circ} \mathrm{C}$. Fractions containing pure peptides were pooled, concentrated in vacuo and desalted on Sephadex G-10 or G-15 with $10 \%$ acetic acid as eluent, lyophilized and dissolved in $3 \mathrm{ml} 10 \%$ acetic acid, and stored in the refrigerator until further investigated.

Separation of chymotryptic peptides. The chymotryptic hydrolysate was separated by chromatography on Dowex 1.X2 as described by Schroeder et al. ${ }^{7}$ and in a previous communication. ${ }^{5}$ The separation was followed by determination of the ninhydrin color of aliquots of the fractions after alkaline hydrolysis, as described earlier. ${ }^{5}$

Peptide maps. The purity of isolated peptides was checked by peptide mapping, as described previously. ${ }^{5}$

Preparative thin-layer chromatography was performed as previously described. ${ }^{5}$

Quantitative amino acid analysis. Peptides were hydrolyzed with constant boiling $\mathrm{HCl}$ at $110^{\circ} \mathrm{C}$, in sealed evacuated tubes as described by Hirs et. al.$^{8}$ Following hydrolysis, the samples were immediately taken to dryness in vacuo in a rotary evaporator, and the amino acids determined with an automatic amino acid analyzer according to Spackman et al., as modified by Samuelsson. ${ }^{10}$

Amino acid sequence analysis. The previously used modification of the Edman degradation ${ }^{5}$ was used also in this work, with the following changes: the benzene washing of the initially formed phenylthiocarbamate was omitted, and the excess of phenylisothiocyanate was instead removed by heating the lyophilized sample at $50^{\circ} \mathrm{C}$ in vacuum for $30 \mathrm{~min} .{ }^{11}$

Detection of amino terminal amino acids by dansylation. Dansylation was performed on $0.01 \mu \mathrm{mol}$ samples of peptides by the procedure of Gros and Labouesse. ${ }^{12}$ Following hydrolysis of the samples, the liberated dansylamino acid was identified by thin layer chromatography according to Stehelin and Duranton. ${ }^{13}$

Digestion with carboxypeptidases and $L A P$. Peptides were digested with these enzymes as previously described. ${ }^{5}$

Partial acid hydrolysis of peptide OT4. $5 \mu \mathrm{M}$ of the peptide was hydrolyzed with 1.0 $\mathrm{ml} 0.1 \mathrm{~N} \mathrm{HCl}$ at $100^{\circ} \mathrm{C}$ for $22 \mathrm{~h}$. The sample was taken to dryness in vacuo, in a rotary evaporator, dissolved in $1 \mathrm{ml} 0.01 \mathrm{M} \mathrm{NaOAc}$ buffer of $\mathrm{pH} 4.3$, and applied to a column $(1 \times 9 \mathrm{~cm})$ of SE-Sephadex previously equilibrated with $0.01 \mathrm{M} \mathrm{NaOAc}$ buffer of pH 5.0. The column was eluted with $110 \mathrm{ml}$ of the buffer used for equilibration and then with $140 \mathrm{ml}$ of $0.1 \mathrm{M} \mathrm{NaOAc}$ buffer, $\mathrm{pH}$ 5.0. Finally the eluent was changed to $0.1 \mathrm{M} \mathrm{NaOAc}$ of $\mathrm{pH} 5.0$ and containing $\mathrm{NaCl}$ to a concentration of $1 \mathrm{M}$. Fractions of $5 \mathrm{ml}$ were collected and their O.D. at $280 \mathrm{~nm}$ determined. Fractions corresponding to UV-absorbing peaks were pooled, desalted on Sephadex G-10 with $10 \%$ acetic acid as eluent, lyophilized and dissolved in $3 \mathrm{ml} 2 \%$ acetic acid. 


\section{RESULTS AND DISCUSSION}

\section{Separation and amino acid sequences of chymotryptic peptides}

The result of chromatography of a chymotryptic hydrolysate of oxidized Viscotoxin A2 on a column of Dowex 1-X2 is illustrated in Fig. 1. Four main

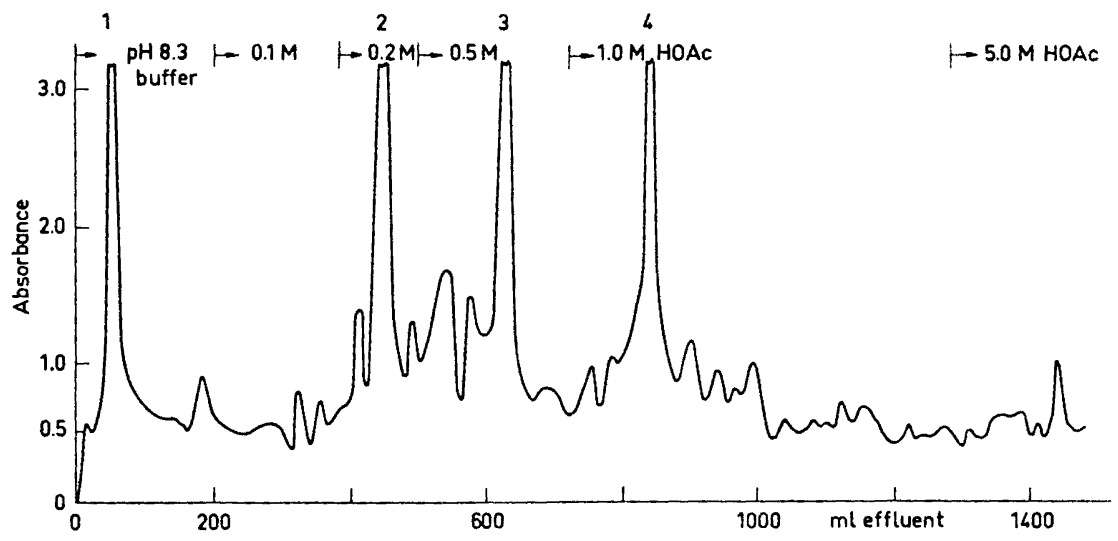

Fig. 1. Chromatography of a chymotryptic hydrolysate of $195 \mathrm{mg}$ of oxidized Viscotoxin A2 on Dowex 1-X2. The composition of the liquid flowing into the mixing chamber is indicated in the upper part.

peaks were obtained, numbered $1-4$ in the figure. Peptide mapping showed peaks 2 and 4 to represent pure peptides. They were designated as peptides $O C 1$ and $O C 4$. Peak 1 as well as the small unnumbered peaks in the chromatogram were found to contain mixtures of peptides, and amino acid analyses showed the yields of these peptides to be small (in the range $1-2.5 \mu \mathrm{mol}$, compared to 7-15 $\mu \mathrm{mol}$ of the main peptides). They were therefore not investigated further.

Peak 3 contained two main peptides, which were separated by preparative thin-layer chromatography. These peptides were designated as peptides OC2 and $O C B$.

The amino acid composition of the four chymotryptic peptides is presented in Table 1. These peptides account for the total amino acid composition of Viscotoxin A2.

Amino acid sequence of peptide OC1. The results of 10 steps of Edman degradation of this peptide are presented in Table 2. After the 10th step, the presence of free leucine was demonstrated by dansylation. These results give the following amino acid sequence for peptide OC1: Gly-Gly-Gly-Ser-ArgGlu-Val-Cys $\left(\mathrm{O}_{3} \mathrm{H}\right)$-Ala-Ser-Leu. Digestion of peptide OC2 with LAP gave no welldefined results. The identification of the -Glu- residue as glutamic acid was performed in connection with determination of the position of the disulfide bridges (to be published elsewhere). A peptide fragment was isolated, which 
Table 1. Amino acid composition of chymotryptic peptides from oxidized Viscotoxin A2.

\begin{tabular}{|c|c|c|c|c|c|c|}
\hline Amino acid & $O C 1$ & $O C 2$ & $O C 3$ & $O C 4$ & Sum & $\begin{array}{c}\text { Oxidized } \\
\text { Viscotoxin } \\
\text { A2 }\end{array}$ \\
\hline $\begin{array}{l}\text { Lysine } \\
\text { Arginine } \\
\text { Cysteic acid } \\
\text { Aspartic acid } \\
\text { Threonine } \\
\text { Serine } a \\
\text { Glutamic acid } \\
\text { Proline } \\
\text { Glycine } \\
\text { Alanine } \\
\text { Valine } \\
\text { Isoleucine } \\
\text { Leucine } \\
\text { Tyrosine } \\
\text { Phenylalanine }\end{array}$ & $\begin{array}{l}2.1 \\
1.0 \\
2.8 \\
1.0 \\
0.9 \\
1.1\end{array}$ & $\begin{array}{l}1.0 \\
1.0 \\
2.0 \\
1.9 \\
1.7 \\
1.0 \\
1.0 \\
1.0\end{array}$ & $\begin{array}{l}0.9 \\
1.0 \\
1.0 \\
1.0\end{array}$ & $\begin{array}{l}2.0 \\
1.9 \\
1.0 \\
1.0 \\
3.7 \\
1.8 \\
1.1 \\
0.9 \\
1.9^{b} \\
0.7\end{array}$ & $\begin{array}{l}3.0 \\
2.7 \\
5.8 \\
3.9 \\
3.7 \\
6.8 \\
1.0 \\
2.8 \\
4.9 \\
1.9 \\
0.9 \\
2.6 \\
1.1 \\
1.1 \\
1.1 \\
\end{array}$ & $\begin{array}{l}3 \\
3 \\
6 \\
4 \\
4 \\
4 \\
7 \\
1 \\
3 \\
5 \\
2 \\
1 \\
3 \\
1 \\
2 \\
1\end{array}$ \\
\hline $\begin{array}{l}\text { Yield, } \mu \mathrm{mol} \\
\text { from about } 32 \\
\mu \mathrm{mol} \text { Viscotoxin } \\
\text { A2 }\end{array}$ & 6.7 & 15 & 15 & 15 & & \\
\hline
\end{tabular}

a Corrected for $10 \%$ loss during hydrolysis.

${ }^{b}$ After hydrolysis for $72 \mathrm{~h}$.

contained this residue as $N$-terminal amino acid. The fragment was obtained by digestion of native Viscotoxin A2 with pepsin, trypsin, and chymotrypsin.

Amino acid sequence of peptide OC2. This peptide was taken through 10 steps of Edman degradation, the results of which are presented in Table 3. Assuming normal chymotryptic specificity the following partial amino acid

Table 2. Edman degradation of peptide $O C 1$.

\begin{tabular}{|c|c|c|c|c|c|c|c|c|c|c|c|}
\hline \multirow{2}{*}{ Amino acid } & \multicolumn{11}{|c|}{ Residues after step No. } \\
\hline & 0 & 1 & 2 & 3 & 4 & 5 & 6 & 7 & 8 & 9 & 10 \\
\hline Arginine & 0.8 & $x$ & 1.0 & $x$ & 1.0 & 0.7 & $x$ & 0.6 & $x$ & 0.6 & $x$ \\
\hline Cysteic acid & 0.9 & 1.0 & 1.0 & 1.1 & 1.0 & 0.9 & 0.9 & 1.0 & 0.7 & 0.8 & 0.8 \\
\hline Serine & 2.1 & 1.8 & 1.8 & 1.8 & 1.6 & 1.6 & 1.5 & 1.4 & $a$ & 1.4 & 1.0 \\
\hline Glutamic acid & 1.0 & 0.9 & 0.9 & 1.0 & 1.0 & 1.1 & 0.7 & 0.7 & $a$ & 0.7 & 0.7 \\
\hline Glycine & 2.8 & 2.1 & 1.5 & 1.0 & 1.0 & 1.1 & 1.0 & 1.0 & 1.1 & 1.1 & 1.0 \\
\hline Alanine & 1.0 & 1.0 & 1.0 & 1.0 & 1.0 & 0.9 & 0.9 & 1.0 & 1.0 & 0.7 & 0.7 \\
\hline Valine & 0.9 & 1.0 & 1.0 & 1.0 & 1.0 & 0.9 & 1.1 & 0.7 & 0.7 & 0.7 & 0.6 \\
\hline Leucine & 1.1 & 0.9 & 1.0 & 1.0 & 1.0 & 1.0 & 1.1 & 0.9 & 1.0 & 0.9 & 0.8 \\
\hline
\end{tabular}

$\times$ Not determined.

a Not determined due to technical error. 
Table 3. Edman degradation of peptide $O C 2$.

\begin{tabular}{|c|c|c|c|c|c|c|c|c|c|c|c|}
\hline \multirow{2}{*}{ Amino acid } & \multicolumn{11}{|c|}{ Residues after step No. } \\
\hline & 0 & 1 & 2 & 3 & 4 & 5 & 6 & 7 & 8 & 9 & 10 \\
\hline Lysine & 1.0 & 0 & 0 & 0 & 0 & 0 & $x$ & $x$ & $x$ & $x$ & $x$ \\
\hline Arginine & 1.0 & 1.0 & 1.0 & 1.0 & 1.0 & 1.0 & $x$ & $x$ & $x$ & $\times$ & 0.7 \\
\hline Cysteic acid & 2.0 & 2.1 & 2.1 & 1.8 & 1.1 & 0.9 & 0.8 & 0.8 & 0.8 & 0.8 & 0.8 \\
\hline Aspartic acid & 1.9 & 1.8 & 1.9 & 1.9 & 1.9 & 1.9 & 1.5 & 1.4 & 1.3 & 1.3 & 1.1 \\
\hline Threonine & 1.7 & 1.7 & 1.7 & 1.7 & 1.8 & 1.8 & 1.7 & 1.3 & 0.9 & 0.9 & 0.8 \\
\hline Serine & 1.0 & 1.1 & 0.8 & 0.6 & 0.5 & 0.4 & 0.5 & 0.3 & 0.3 & 0.3 & 0.3 \\
\hline Proline & 1.0 & 1.0 & 1.0 & 1.0 & 0.9 & 0.7 & 0.5 & 0.4 & 0.4 & 0.4 & 0.4 \\
\hline Glycine & 1.0 & 1.0 & 1.0 & 1.0 & 1.0 & 1.0 & 1.0 & 0.9 & 0.9 & 0.7 & 0.6 \\
\hline Isoleucine & 0.7 & 0.7 & 0.8 & 0.8 & 0.8 & 0.8 & 0.8 & 0.8 & 0.8 & 0.7 & 0.7 \\
\hline Tyrosine & 0.4 & 0.6 & 0.7 & 0.7 & 0.7 & 0.7 & 0.7 & 0.7 & $a$ & 0.6 & $a$ \\
\hline
\end{tabular}

$\times$ Not determined.

a Not determined due to technical error.

sequence can be deduced for this peptide: Lys-Ser-Cys $\left(\mathrm{O}_{3} \mathrm{H}\right)-\mathrm{Cys}\left(\mathrm{O}_{3} \mathrm{H}\right)$ Pro-Asx-Thr-Thr-Gly-Arg-(Asx, Ile)-Tyr. As lysine has been demonstrated to be the amino terminal amino acid of Viscotoxin A2, this peptide is the amino terminal fragment of the protein.

Amino acid sequence of peptide OC3. Three steps of Edman degradation of this peptide are presented in Table 4. The presence of free phenylalanine was demonstrated after completion of the fourth step. Thus, the amino acid sequence of peptide $O C 3$ is: $A s x-T h r-C y s\left(O_{3} H\right)$-Arg-Phe.

Amino acid sequence of peptide OC4. Table 5 shows the results of 9 steps of Edman degradation of this peptide. The following partial amino acid sequence can be deduced: Ser-Gly-Cys $\left(\mathrm{O}_{3} \mathrm{H}\right)-\mathrm{Lys}-I l e-I l e-S e r-A l a-S e r-\left(T h r, C y s\left(\mathrm{O}_{3} \mathrm{H}\right)\right.$, 2 Pro,Ser,Tyr,Asx,Lys).

The presence of an Ile-Ile bond is assumed from the low yields of isoleucine when the peptide is hydrolyzed under normal conditions $\left(24 \mathrm{~h}\right.$ at $\left.110^{\circ} \mathrm{C}\right)$ and the fact that no decrease in any amino acid is demonstrated in step 4 , but a $50 \%$ decrease in isoleucine is found in the 5th step.

Table 4. Edman degradation of peptide OC3.

\begin{tabular}{|l|c|c|c|c|}
\hline \multirow{2}{*}{ Amino acid } & \multicolumn{4}{|c|}{ Residues after step No. } \\
\cline { 2 - 5 } & 0 & 1 & 2 & 3 \\
\hline Arginine & 0.9 & $\times$ & $\times$ & 0.8 \\
Cysteic acid & 1.0 & 1.0 & 1.0 & 0.6 \\
Aspartic acid & 1.0 & 0.4 & 0.4 & 0.4 \\
Threonine & 1.0 & 1.0 & 0.7 & 0.5 \\
Phenylalanine & 1.1 & 1.2 & 1.1 & 1.0 \\
\hline
\end{tabular}

$\times$ Not determined.

Acta Chem. Scand. 26 (1972) No. 2 
Table 5. Edman degradation of peptide OC4.

\begin{tabular}{|l|c|c|c|c|c|c|c|c|c|c|}
\hline & \multicolumn{10}{|c|}{ Residues after step No. } \\
\cline { 2 - 10 } & 0 & 1 & 2 & 3 & 4 & 5 & 6 & 7 & 8 & 9 \\
\hline Lysine & 2.0 & $\times$ & 2.0 & 2.0 & 1.1 & 1.0 & 1.0 & 1.0 & 1.0 & $\times$ \\
Cysteic acid & 1.9 & 2.0 & 2.2 & 1.5 & 1.4 & 1.4 & 1.3 & 1.4 & 1.2 & 1.3 \\
Aspartic acid & 1.0 & 1.2 & 1.2 & 1.2 & 1.0 & 1.0 & 1.0 & 1.0 & 1.1 & 1.1 \\
Threonine & 1.0 & 1.1 & 1.1 & 1.0 & 1.0 & 0.9 & 1.0 & 0.9 & 0.9 & 0.8 \\
Serine & 3.7 & 2.9 & 2.8 & 2.7 & 2.5 & 2.5 & 2.5 & 2.0 & 1.9 & 1.4 \\
Proline & 1.8 & 2.1 & 1.7 & 1.8 & 1.7 & 1.8 & 1.8 & 1.8 & 1.8 & 1.7 \\
Glycine & 1.1 & 1.2 & 0.6 & 0.5 & 0.4 & 0.4 & 0.4 & 0.4 & 0.4 & 0.4 \\
Alanine & 0.9 & 1.2 & 1.0 & 1.0 & 1.0 & 1.0 & 0.9 & 0.9 & 0.5 & 0.5 \\
Isoleucine & $1.9^{a}$ & 1.3 & 0.9 & 0.9 & 0.8 & 0.8 & 0.4 & 0.5 & 0.4 & 0.5 \\
Tyrosine & 0.7 & 0.6 & 0.7 & 0.7 & 0.8 & 0.7 & 0.7 & 0.8 & 0.8 & $b$ \\
\hline
\end{tabular}

$\times$ Not determined.

a After hydrolysis for $72 \mathrm{~h}$.

$b$ Not determined due to technical error.

Isolation and amino acid sequences of tryptic peptides

The tryptic hydrolysate of oxidized Viscotoxin A2 was separated into two fractions, by gel filtration on Sephadex G-25. These fractions were then chromatographed on a column of Dowex 1-X2 and the separation followed by thin-layer chromatography of the fractions of the eluate. Five pure peptides were obtained. They were designated as peptides OT1, OT2, OT 3, OT4, and OT5. The amino acid compositions of these peptides are presented in Table 6 . Besides these main peptides there were also a number of peptides, the yields of which were low ( $1-2 \mu \mathrm{mol}$ compared to $15-22 \mu \mathrm{mol}$ of the main peptides). These peptides were not further investigated.

Amino acid sequence of peptide OT1. 8 steps of Edman degradation of this peptide are presented in Table 7. Digestion with carboxypeptidases A and B liberated arginine followed by glycine, threonine, and asparagine. The following partial amino acid sequence can be deduced for this peptide: Lys-Ser$\mathrm{Cys}\left(\mathrm{O}_{3} \mathrm{H}\right)-\mathrm{Cys}\left(\mathrm{O}_{3} \mathrm{H}\right)$-Pro-Asn-Thr-(Thr,Gly)-Arg. This sequence corresponds to the sequence of the first 10 amino acids of peptide $O C 2$.

Amino acid sequence of peptide OT2. This peptide was taken through 4 steps of Edman degradation, the results of which are presented in Table 8. Free arginine was demonstrated to be present after completion of the 5th degradation step. The amino acid sequence of peptide OT2 is: Phe-Gly-Gly Gly-Ser-Arg. As Viscotoxin A2 contains only one residue of phenylalanine, this sequence forms an overlap between peptides $O C 3$ and $O C 1$.

Amino acid sequence of peptide OT3. The results of 5 steps of Edman degradation are presented in Table 9. Free arginine was demonstrated to be present after completion of the 6th degradation step. Digestion with LAP showed the presence of asparagine. The amino acid sequence of peptide OT3 is: 
Table 6. Amino acid composition of tryptic peptides from oxidized Viscotoxin A2.

\begin{tabular}{|c|c|c|c|c|c|}
\hline Amino acid & OT1 & OT2 & OT3 & OT4 & OT5 \\
\hline $\begin{array}{l}\text { Lysine } \\
\text { Arginine } \\
\text { Cysteic acid } \\
\text { Aspartic acid } \\
\text { Threonine } \\
\text { Serine } \\
\text { Glutamic acid } \\
\text { Proline } \\
\text { Glycine } \\
\text { Alanine } \\
\text { Valine } \\
\text { Isoleucine } \\
\text { Leucine } \\
\text { Tyrosine } \\
\text { Phenylalanine }\end{array}$ & $\begin{array}{l}1.0 \\
1.0 \\
2.3 \\
1.1 \\
1.9 \\
1.0 \\
\\
1.0 \\
1.1\end{array}$ & 1.1 & $\begin{array}{l}1.1 \\
1.2 \\
1.9 \\
0.8\end{array}$ & $\begin{array}{l}1.1 \\
1.1 \\
1.0 \\
0.9 \\
2.9 \\
1.9 \\
0.9 \\
\\
1.9^{a} \\
0.9\end{array}$ & $\begin{array}{c}0.9 \\
2.2 \\
1.0 \\
1.8 \\
0.9 \\
\\
1.0 \\
1.1\end{array}$ \\
\hline $\begin{array}{l}\text { Yield, } \mu \mathrm{mol} \text { from } \\
\text { about } 33 \mu \mathrm{mol} \text { oxid. } \\
\text { Viscotoxin A2 }\end{array}$ & 20 & 20 & 15 & 22 & 3 \\
\hline
\end{tabular}

a After hydrolysis for $72 \mathrm{~h}$.

Asn-Ile-Tyr-Asn-Thr-Cys $\left(\mathrm{O}_{3} \mathrm{H}\right)$-Arg. This sequence forms an overlap between the chymotryptic peptides $O C 2$ and $O C 3$.

The amino acid sequence of peptide OT4. 11 steps of Edman degradation are presented in Table 10. Dansylation confirmed that the amino terminal residue is isoleucine. Digestion with carboxypeptidase $B$ liberated lysine, and digestion with a mixture of carboxypeptidases $\mathrm{A}$ and $\mathrm{B}$ liberated lysine and

Table 7. Edman degradation of peptide OT1.

\begin{tabular}{|l|c|c|c|c|c|c|c|c|}
\hline \multirow{2}{*}{ Amino acid } & \multicolumn{10}{|c|}{ Residues after step No. } \\
\cline { 2 - 8 } & 0 & 1 & 2 & 3 & 4 & 5 & 6 & 7 \\
\hline Lysine & 1.0 & 0.4 & $\times$ & $\times$ & $\times$ & $\times$ & $\times$ & $\times$ \\
Arginine & 0.9 & 0.9 & $\times$ & $\times$ & $\times$ & $\times$ & $\times$ & $\times$ \\
Cysteic acid & 2.3 & 2.0 & 2.0 & 1.3 & 1.0 & 1.0 & 1.0 & 1.0 \\
Aspartic acid & 1.1 & 1.0 & $a$ & 1.0 & 1.0 & 1.0 & 0.6 & 0.6 \\
Threonine & 1.9 & 1.9 & 1.7 & 1.8 & 1.7 & $a$ & 1.7 & 0.8 \\
Serine & 1.0 & 1.1 & 0.4 & 0.3 & 0.3 & 0 & 0 & 0 \\
Proline & 1.0 & 1.1 & 1.1 & 1.1 & 0.9 & 0.5 & 0.6 & 0.5 \\
Glycine & 1.1 & 1.1 & 1.0 & 1.2 & 1.0 & 1.1 & 0.9 & 0.9 \\
\hline
\end{tabular}

$\times$ Not determined.

a Not determined due to technical error.

Acta Chem. Scand. 26 (1972) No. 2 
Table 8. Edman degradation of peptide OT2.

\begin{tabular}{|l|c|c|c|c|c|}
\hline \multirow{2}{*}{ Amino acid } & \multicolumn{5}{|c|}{ Residue after step No. } \\
\cline { 2 - 6 } & 0 & 1 & 2 & 3 & 4 \\
\hline Arginine & 1.1 & $\times$ & $\times$ & $\times$ & $\times$ \\
Serine & 0.9 & 0.8 & 0.8 & 0.8 & 0.8 \\
Glycine & 3.1 & 2.9 & 2.4 & 1.5 & 0.6 \\
Phenylalanine & 1.0 & 0 & 0 & 0 & 0 \\
\hline
\end{tabular}

$\times$ Not determined.

Table 9. Edman degradation of peptide OT3.

\begin{tabular}{|l|c|c|c|c|c|c|}
\hline \multirow{2}{*}{ Amino acid } & \multicolumn{7}{|c|}{ Residues after step No. } \\
\cline { 2 - 7 } & 0 & 1 & 2 & 3 & 4 & 5 \\
\hline Arginine & 1.1 & $\times$ & $\times$ & $\times$ & $\times$ & $\times$ \\
Cysteic acid & 1.2 & 1.3 & 1.2 & 1.2 & 1.2 & 1.0 \\
Aspartic acid & 1.9 & 1.1 & 1.0 & 1.1 & 0.4 & 0.2 \\
Threonine & 0.8 & 0.8 & 0.7 & 0.9 & 1.0 & 0.3 \\
Isoleucine & 0.9 & 0.9 & 0.1 & 0.1 & 0.1 & 0.1 \\
Tyrosine & 0.7 & 0.5 & 0.7 & 0.1 & 0.1 & 0.1 \\
\hline
\end{tabular}

$\times$ Not determined.

Table 10. Edman degradation of peptide OT4.

\begin{tabular}{|c|c|c|c|c|c|c|c|c|c|c|c|c|}
\hline \multirow{2}{*}{ Amino acid } & \multicolumn{12}{|c|}{ Residues after step No. } \\
\hline & 0 & 1 & 2 & 3 & 4 & 5 & 6 & 7 & 8 & 9 & 10 & 11 \\
\hline Lysine & 1.0 & 1.1 & $x$ & $x$ & $x$ & $x$ & $x$ & $x$ & $x$ & $x$ & $x$ & $x$ \\
\hline Cysteic acid & 1.1 & 1.2 & 1.1 & 1.1 & 1.0 & 1.0 & 1.0 & 0.7 & 0.7 & 0.5 & 0.6 & 0.4 \\
\hline Aspartic acid & 1.0 & 1.1 & 1.0 & 0.9 & 1.0 & 1.0 & 1.0 & 1.0 & 1.0 & 1.0 & 0.9 & 0.9 \\
\hline Threonine & 1.0 & 1.0 & 0.9 & 0.9 & 0.8 & 0.8 & 0.6 & 0.4 & 0.4 & 0.4 & $a$ & 0.3 \\
\hline Serine & 2.9 & 2.8 & 2.2 & 1.4 & 1.3 & 1.1 & 1.2 & 1.1 & 1.1 & 0.9 & $a$ & 0.9 \\
\hline Proline & 1.9 & 2.1 & 1.9 & 2.0 & 1.9 & 1.9 & 2.0 & 2.0 & 1.5 & 1.5 & 1.6 & 1.4 \\
\hline Alanine & 0.9 & 1.1 & 0.9 & 1.1 & 0.2 & 0.2 & 0.2 & 0.2 & 0.2 & 0.2 & 0.2 & 0.2 \\
\hline Isoleucine & $1.9^{b}$ & $1.1^{b}$ & $0.1^{b}$ & 0.2 & 0.1 & 0.1 & 0.1 & 0.1 & 0.1 & 0.1 & 0.1 & 0.1 \\
\hline Tyrosine & 0.9 & 0.9 & 0.4 & 0.3 & 0.6 & 0.7 & $a$ & 0.8 & 0.9 & 0.9 & 0.7 & 0.7 \\
\hline
\end{tabular}

$\times$ Not determined.

${ }^{a}$ Not determined due to technical error.

$b$ After hydrolysis for 72 hours. 
aspartic acid, thus indicating the C-terminal amino acid sequence to be -AspLys. These results permit deduction of the following amino acid sequence for peptide OT4: Ile-Ile-Ser-Ala-Ser-Thr-Cys $\left(O_{3} H\right)$-Pro-Ser-Tyr-Pro-Asp-Lys. To check this sequence the peptide was also subjected to partial acid hydrolysis and the hydrolysate chromatographed on a column of SE-Sephadex, the result of which is presented in Fig. 2. Two peaks were obtained. The first peak was

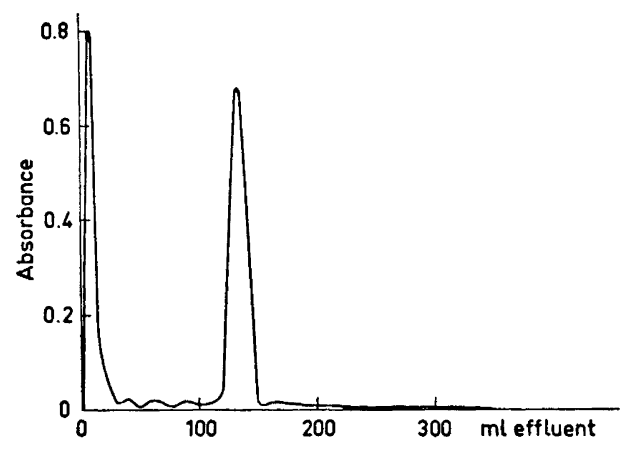

Fig. 2. Separation of a partial acid hydrolysate of peptide OT4 on SE-Sephadex. For details, see text.

shown to be a mixture of free amino acids and peptides. The second peak was a pure dipeptide containing the amino acids tyrosine and proline. Dansylation showed the amino terminal residue to be tyrosine, thus confirming that the sequence Tyr-Pro is present in peptide OT4. The sequence of the first 5 amino acid residues of peptide $O T 4$ is the same as the sequence of residues $5-9$ of peptide $O C 4$. It is therefore concluded that the undetermined sequence of peptide $O C 4$ is the same as the sequence of residues $6-13$ of peptide OT4.

Peptide OT5. This peptide was obtained in the comparatively low yield of $3 \mu \mathrm{mol}$. As seen from Table 6 the amino acid composition of this peptide is the same as that of peptide OT1 minus one residue of lysine. Dansylation showed the amino terminal residue to be serine. Digestion with carboxypeptidase $\mathrm{B}$ liberated arginine which thus is the $C$-terminal amino acid. Carboxypeptidase $\mathrm{A}+\mathrm{B}$ liberated arginine, glycine, and threonine. It is therefore concluded that peptide $O T 5$ has been formed from peptide $O T 1$ by incomplete tryptic hydrolysis.

The complete amino acid sequence of $\mathrm{V}$ is cotoxin A 2

The sequences of the tryptic peptides OT2 and OT3 show that the chymotryptic peptides $O C 1, O C 2$, and $O C 3$ must be linked together in the sequence $O C 2-O C 3-O C 1$. Since peptide $O C 2$ represents the amino terminal sequence of Viscotoxin A2, peptide OC4 must represent the carboxyl terminal

Acta Chem. Scand. 26 (1972) No. 2 


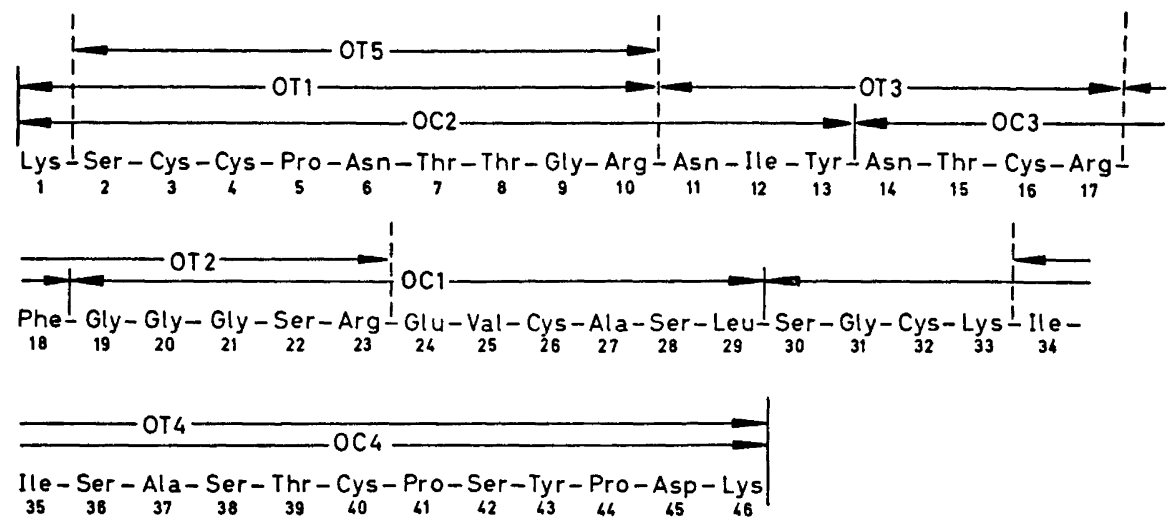

Fig. 3. The amino acid sequence of Viscotoxin A2.

sequence and the four chymotryptic peptides are thus linked together in the intact protein in the order $O C 2-O C 3-O C 1-O C 4$, thus establishing the complete amino acid sequence of Viscotoxin A2 as presented in Fig. 3. The sites of attack by trypsin and chymotrypsin are indicated in the figure. It is also obvious that the number of tryptic peptides isolated is not complete. One fragment containing the amino acids $24-33$ is missing from the series of tryptic peptides. This fragment must have a very low isoelectric point as it contains two residues of cysteic acid and one residue of glutamic acid balanced only by one residue of lysine. It is therefore very probable that this fragment was so strongly adsorbed on the Dowex 1-X2 column that it could not be eluted under the conditions employed.

The amino acid sequence of Viscotoxin A2 is very similar to that of Viscotoxin A3..$^{5}$ The 6 half-cystine residues are all in the same position in the two proteins. The amino acid sequence of residues $1-14,16,17,20,23,26$, $27,29-36$, and $38-46$ are the same. The main difference is found in the sequence of residues $18-25$, where only two residues are the same in both proteins. The presence of glutamic acid at position 24 and the absence of lysine at position 28 are noteworthy.

Acknowledgements. This work was supported by grants from the Swedish Medical Research Council (Projects Nos. B-59-13X-2084-03A, B70-13X-2084-04B, and B71-13X2084-05C).

\section{REFERENCES}

1. Winterfeld, K. and Bijl, L. M. Ann. 561 (1948) 107.

2. Samuelsson, G. Svensk Farm. Tidskr. 65 (1961) 481.

3. Olson, T. and Samuelsson, G. Acta Chem. Scand. 24 (1970) 720.

4. Samuelsson, G. and Pettersson, B. Acta Chem. Scand. 24 (1970) 2751.

5. Samuelsson, G., Seger, L. and Olson, T. Acta Chem. Scand. 22 (1968) 2624.

6. Hirs, C. H. W. J. Biol. Chem. 219 (1956) 611.

7. Schroeder, W. A., Jones, R. T., Cormick, J. and McCalla, K. Anal. Chem. 34 (1962) 1570 . 
8. Hirs, C. H. W., Stein, W. H. and Moore, S. J. Biol. Chem. 211 (1954) 941.

9. Spackman, D. H., Stein, W. H. and Moore, S. Anal. Chem. 30 (1958) 1190.

10. Samuelsson, G. Svensk Kem. Tidskr. 80 (1967) 98.

11. Blombäck, B. Personal communication.

12. Gros, C. and Labouesse, B. European J. Biochem. 7 (1969) 463.

13. Stehelin, D. and Duranton, H. J. Chromatog. 43 (1969) 93.

Received May 8, 1971.

Acta Chem. Scand. 26 (1972) No. 2 